\title{
Characteristics of Adults' Use of Facebook and the Potential Impact on Health Behavior: Secondary Data Analysis
}

Kelly Bosak, PhD, ANP-BC; Shin Hye Park, PhD, RN

School of Nursing, University of Kansas Medical Center, Kansas City, KS, United States

Corresponding Author:

Kelly Bosak, PhD, ANP-BC

School of Nursing

University of Kansas Medical Center

3901 Rainbow Boulevard

Mailstop 4043

Kansas City, KS, 66160

United States

Phone: 19135881656

Fax: 19135881660

Email:kbosak@kumc.edu

\section{Abstract}

Background: Social influences are a primary factor in the adoption of health behaviors. Social media platforms, such as Facebook, disseminate information, raise awareness, and provide motivation and support for positive health behaviors. Facebook has evolved rapidly and is now a part of many individuals' daily routine. The high degree of individual engagement and low attrition rate of this platform necessitate consideration for a potentially positive impact on health behavior.

Objective: The aim of this paper is to investigate the use of Facebook by adults. Knowledge is limited to the unique characteristics of Facebook users, including time spent on Facebook by adults of various age groups. Characteristics of Facebook users are important to understand to direct efforts to engage adults in future health behavior interventions.

Methods: Institutional Review Board approval was obtained for this secondary analysis of existing de-identified survey data collected for the Pew Research Center. The sample included adults age 18-65 years and above. Binomial logistic regression was performed for the model of age group and Facebook use, controlling for other demographics. A multinomial logistic regression model was used for the variable of time spent on Facebook. Based on the regression models, we computed and reported the marginal effects on Facebook use and time spent of adults age groups, including age groups 18-29, 30-49, 50-64, and 65 and over. We discuss these findings in the context of the implications for promoting positive health behaviors.

Results: The demographics of the final sample ( $\mathrm{N}=730)$ included adults age 18-65 years and above (mean 48.2 yrs, SD 18.3 yrs). The majority of the participants were female (372/730, 50.9\%), white (591/730, 80.9\%) and non-Hispanic $(671 / 730,91.9 \%)$. Bivariate analysis indicated that Facebook users and nonusers differed significantly by age group $\left(\chi^{2}=76.71, P<.001\right)$ and sex $\left(\chi^{2}=9.04, P=.003\right)$. Among subjects aged 50 and above, the predicted probability was $66 \%$ for spending the same amount of time, $10 \%$ with increased time, and $24 \%$ with decreased time.

Conclusions: The key findings of this study were Facebook use among midlife and older adults was more likely to stay the same over time, compared to the other age groups. Interestingly, the young adult age group 18-29 years was more likely to decrease their time on Facebook over time. Specifically, younger females were most likely to decrease time spent on Facebook. In general, male participants were most likely to spend the same amount of time on Facebook. These findings have implications for future health intervention research, and ultimately, for translation to the clinic setting to improve health outcomes.

(Interact J Med Res 2018;7(1):e11) doi: 10.2196/ijmr.9554

\section{KEYWORDS}

social media; health promotion; health behavior; adults 


\section{Introduction}

\section{Background}

Social media has evolved rapidly and has been used as a means of communication, social interaction, and social support with minimal consideration for wider use in health care. It is recognized that social influences are an important factor in the adoption of health behaviors [1,2]. Despite the growing interest in practical research and the development and implementation of health behavior interventions in real-world settings, social media is often overlooked as an effective method to deliver the active components of a health behavior intervention. To accomplish this requires knowledge of the characteristics of social media use among the population of interest for integration in a health behavior intervention.

\section{Significance}

The use of the social media is deeply embedded in everyday life for an increasing number of adults [3]. The widely recognized, accessed, and the culturally integrated Facebook platform has an extensive reach, with over one billion daily adult users and continues to grow [4].

The Facebook platform has been used effectively to recruit participants for health behavior research [5], to provide online health information and education [6,7] as well as the more familiar social networking functions. This platform has been used as an adjunct to multimodal interventions or in conjunction with investigator-initiated in-person visits and other methods of communication, such as mobile phones, text messages, and apps [8-11]. Facebook used as a means for patients to communicate with other patients is a trend referred to as peer-to-peer health care [12]. These functions of Facebook are widely recognized; however, peer support is only a small part of the potential of this platform to improve health outcomes.

Facebook offers the capability to create groups via the platform referred to as "Facebook Groups." This group platform offers a convenient, reliable, private, members-only site that can be adapted to motivate and support health behavior change interventions and conduct research. This platform also allows integration into clinic processes, with health care professionals serving as moderators and contributors of the content to ensure its' veracity. Efficacious health behavior interventions translated into real-life settings for effectiveness testing require the ability to appeal to and influence a broad and diverse population of participants. This necessitates an understanding of the characteristics of Facebook use of potential participants from the population of interest.

A distinct advantage of using the Facebook platform to facilitate a health behavior intervention is the high level of individual engagement. This is an important factor in promoting positive health behavior change. Engagement in an intervention is critical for participants to receive an adequate dose of the intervention [13], and thus, improve health outcomes. Attrition is very low on this platform, although some individual users occasionally take breaks from social media use [4]. Minimizing attrition may support long-term maintenance of health behaviors. The high levels of engagement and retention on Facebook over time may translate to the Facebook Groups platform making this an appealing method for delivering the active components of a health behavior intervention. Interventions facilitated by social media platforms hold promise to reduce the challenges for the growing population of midlife adults to prevent or delay the progression of chronic health conditions [14].

Few studies reported health behavior interventions facilitated by social media platforms to provide the active components of an intervention. A review found positive outcomes with $87.5 \%$ (7/8) of the studies involving physical activity interventions delivered using Facebook [15]. Other research found that Facebook user engagement and social support predicted a reduction in smoking [16]. Features of the Facebook Groups platform to promote cardiac rehabilitation included participant only access with a health care provider involved as group moderator to provide evidence-based information and assure "trustworthiness" of the group [17]. Greater Facebook capability may increase willingness to participate in the Facebook Groups platform. Trends show that adults across the age continuum are capable users of this technology [18]. Further, participants may be more likely to engage on the Facebook Groups platform upon the recommendation of their health care provider. Earlier studies reported that some older adults had concerns about the usefulness of combining health resources with social media [19]. Social media use has advanced since its' inception and is now being used by younger adults as well as older adults to influence health. Therefore, we investigated the characteristics of adult Facebook users to inform our future research on the Facebook Groups platform.

\section{Study Objective}

The objective of this study was to investigate the use of the social media platform, Facebook by adults (aged 18-65 years and above). Knowledge is limited to the characteristics of Facebook use by adults across the age continuum, necessitating this investigation. Characteristics of Facebook users are important to understand to guide the development of a future clinical trial using the social media platform, Facebook Groups to deliver the active components of a health behavior intervention.

\section{Methods}

\section{Design}

The Institutional Review Board at the University where this study was conducted approved this study as exempt from full board review due to the use of de-identified data. The design was a secondary analysis of survey data. The sample included adults across the age continuum (18-65 years and above). Participants were included in our analysis based on the following: (a) they responded "yes" to the initial question: "Do you use the internet?" (b) they were able to provide informed verbal consent by phone, and (c) they were able to speak and understand English or Spanish, as the survey was not conducted in any other languages.

\section{Data Collection}

The Pew Research Center surveyed a representative sample of adults across all regions of the continental United States about 
their use of the social media platform, Facebook [20]. This national self-report survey was conducted between November 14, 2012 and December 9, 2012, on landlines and cell phones, and in English and Spanish by Princeton Survey Research Associates International. Multiple attempts were made to reach each phone number at a variety of times throughout the day. The survey consisted of 20 items rated on a Likert-type scale or a true and false format. We selected the sociodemographic and Facebook use the variables: user or nonuser, and time spent using Facebook stayed about the same, increased or decreased for this analysis.

\section{Data Analysis}

We described demographics by adults' use of Facebook and time spent on Facebook, using chi-squared tests for categorical variables. Fisher's exact test was used for two variables due to small cell counts as noted. Multivariate binomial logistic regression was performed for the model of Facebook use (users and nonusers) on age group, controlling for other demographics, including sex, income, employment, race and ethnicity, and education. A multivariate, multinomial logistic regression model was used for our secondary outcome variable, regressing time spent on Facebook (stayed about the same, increased, and decreased) on age groups and other demographic variables. We also questioned whether the effects of age group on Facebook use and time spent would differ by sex. Therefore, after performing multivariate regression, we calculated marginal effects to show the interactions between age group and sex in the models. The marginal effects were interpreted as the predicted probability of using Facebook or time spent on Facebook for participants of a specific age group and sex, holding all other demographics constant to the means. We discuss these findings in the context of the implications for health behavior change. All data were analyzed using the STATA Version 14.0 (StataCorp, LP, College Station, TX, USA).

\section{Results}

The demographics of the sample $(\mathrm{N}=730)$ are shown in Table 1 and included adults age 18-65 years and above with a mean of 50.3 (SD 19.7) years. The majority of the participants interviewed were white $(591 / 730,80.9 \%)$ and non-Hispanic or another ethnicity $91.9 \%$ (671/730). There were 50.9\% (372/730) females and $49.0 \%(358 / 730)$ males responding to the survey. Some college or college graduation was reported by $69.0 \%$ $(504 / 730)$ of the respondents. Half (365/730) of the sample reported full-time employment, with just over half (380/730, $52.0 \%$ ) reporting an income between US $\$ 30,000$ and US $\$ 100,000$. The majority $(462 / 730,63.2 \%)$ surveyed were Facebook users, and 52.0\% (380/730) reported their time spent on Facebook stayed the same over the past year.
The bivariate analysis (Table 2) indicated that Facebook users and nonusers differed significantly by age group $(\mathrm{N}=730$, $\left.\chi_{3}^{2}=76.7, P<.001\right)$, and sex $\left(\mathrm{N}=730, \chi_{1}^{2}=9.0, P=.003\right)$. There were no significant differences in Facebook users and nonusers based on income, employment status, race and ethnicity, or education level.

The bivariate analysis (see Table 3) indicated that time spent on Facebook (ie, stayed about the same, increased, and decreased) differed significantly by age group $\left(n=461, \chi^{2}{ }_{6}=31.8\right.$, $P<.001)$. No differences were found in time spent on Facebook based on income, employment status, race, or education. Notably, ethnicity was significant $\left(n=461, \chi_{2}^{2}=5.3, P=.045\right)$ using Fisher's exact test.

Based on our bivariate results, we examined whether the effects of age group differed by sex. Table 4 shows significant variations in the marginal effects of age group by sex on Facebook use. Younger and female subjects were more likely to use Facebook than older and male subjects. The probability of using Facebook was 87\% among participants aged 18-29 years and differed by sex. The probability of using Facebook among participants aged 18-29 was $91 \%$ for female, whereas it was $83 \%$ for male. The probability of using Facebook among participants aged 65 and over was $45 \%$ for female, whereas it was $27 \%$ for male. Figure 1 shows the marginal effects of age group by sex on Facebook decreasing across age groups.

Table 5 shows marginal effects of age group and sex across the three subgroups of Facebook time (stayed the same, increased, and decreased). Due to small cell counts in age group 65+ and Asian group (Table 3 ) we regrouped the age variable into three groups (18-29, 30-49, and 50+) and the race variable into three groups (white, black or African American, and others) for analysis of time spent using Facebook.

Overall, subjects in the group that increased amount of time on Facebook showed the lowest probabilities than those in the other groups. Among subjects aged 50 and above, the predicted probability was $66 \%$ for spending the same amount of time, $10 \%$ with increased time, and $24 \%$ with decreased time. Older subjects were more likely to spend the same amount of time and less likely to decrease time on Facebook. Younger participants were more likely to decrease time on Facebook.

Among older males, the predicted probabilities for time spent using Facebook were $70 \%$ stayed the same, $8 \%$ increased, and $22 \%$ decreased time on Facebook. The predicted probabilities for Facebook use among women in this age group were similar with $64 \%$ stayed the same, $11 \%$ increased, and $26 \%$ decreased time spent on Facebook. Figures 2-4 show the marginal effects of age group by sex on Facebook use for the variables: stayed about the same (Figure 2), increased (Figure 3), and decreased (Figure 4). 
Table 1. Descriptive summary of demographic characteristics and outcome variables.

\begin{tabular}{|c|c|}
\hline Variables & Value $(\mathrm{N}=730), \mathrm{n}(\%)$ \\
\hline \multicolumn{2}{|l|}{ Age group (years) } \\
\hline $18-29$ & $152(20.8)$ \\
\hline $30-49$ & $232(31.8)$ \\
\hline $50-64$ & $191(26.2)$ \\
\hline $65+$ & $155(21.2)$ \\
\hline \multicolumn{2}{|l|}{ Sex } \\
\hline Male & $358(49.0)$ \\
\hline Female & $372(51.0)$ \\
\hline \multicolumn{2}{|l|}{ Income (US\$) } \\
\hline$<\$ 30,000$ & $219(30.0)$ \\
\hline$\$ 30,000-\$ 100,000$ & $380(52.1)$ \\
\hline$>\$ 100,000$ & $131(17.9)$ \\
\hline \multicolumn{2}{|l|}{ Employment } \\
\hline Full-time & $362(49.6)$ \\
\hline Part-time & $104(14.2)$ \\
\hline Not employed & $264(36.2)$ \\
\hline \multicolumn{2}{|l|}{ Race } \\
\hline Caucasian & $589(80.7)$ \\
\hline African-American & $77(10.5)$ \\
\hline Asian or Pacific Islander & $19(2.6)$ \\
\hline Other & $45(6.2)$ \\
\hline \multicolumn{2}{|l|}{ Ethnicity } \\
\hline Hispanic & $61(8.4)$ \\
\hline Not Hispanic or other & $669(91.6)$ \\
\hline \multicolumn{2}{|l|}{ Education } \\
\hline$\leq$ High school & $223(30.5)$ \\
\hline$\geq$ College & $507(69.5)$ \\
\hline \multicolumn{2}{|l|}{ Facebook users } \\
\hline Users & $462(63.3)$ \\
\hline Nonusers & $268(36.7)$ \\
\hline \multicolumn{2}{|l|}{ Time spent on Facebook $^{\mathrm{a}}$} \\
\hline Stayed the same & $382(52.3)$ \\
\hline Increased & $96(13.2)$ \\
\hline Decreased & $252(34.5)$ \\
\hline
\end{tabular}

${ }^{a}=461$. This subgroup was from Facebook users only and those responding to the item of time spent on Facebook. 
Table 2. Bivariate statistics by Facebook users and nonusers.

\begin{tabular}{|c|c|c|c|c|c|}
\hline Variable & $\begin{array}{l}\text { Full sample } \\
(\mathrm{N}=730), \mathrm{n}(\%)\end{array}$ & $\begin{array}{l}\text { Facebook users } \\
(\mathrm{N}=462), \mathrm{n}(\%)\end{array}$ & $\begin{array}{l}\text { Facebook nonusers } \\
(n=268), n(\%)\end{array}$ & Chi-square (df) & $P$ value \\
\hline Age group (years) & & & & $76.7(3)$ & $<.001$ \\
\hline $18-29$ & $152(20.8)$ & $129(27.9)$ & $23(8.6)$ & & \\
\hline $30-49$ & $232(31.8)$ & $163(35.3)$ & $69(25.7)$ & & \\
\hline $50-64$ & $191(26.2)$ & $109(23.6)$ & $82(30.6)$ & & \\
\hline $65+$ & $155(21.2)$ & $61(13.2)$ & $94(35.1)$ & & \\
\hline Sex & & & & $9.0(1)$ & .003 \\
\hline Male & $358(49.0)$ & $207(44.8)$ & $151(56.3)$ & & \\
\hline Female & $372(51.0)$ & $255(55.2)$ & $117(43.7)$ & & \\
\hline Income (US \$) & & & & $0.6(2)$ & .748 \\
\hline$<\$ 30,000$ & $219(30.0)$ & $140(30.3)$ & $79(29.5)$ & & \\
\hline$\$ 30,000-\$ 100,000$ & $380(52.1)$ & $236(51.1)$ & $144(53.7)$ & & \\
\hline$>\$ 100,000$ & $131(17.9)$ & $86(18.7)$ & $45(16.9)$ & & \\
\hline Employment & & & & $5.6(2)$ & .062 \\
\hline Full-time & $362(49.6)$ & $237(51.3)$ & $125(46.6)$ & & \\
\hline Part-time & $104(14.2)$ & $73(15.7)$ & $32(12.0)$ & & \\
\hline Not employed & $264(36.2)$ & $153(33.1)$ & $111(41.4)$ & & \\
\hline Race & & & & $6.9(3)$ & .076 \\
\hline White & $589(80.7)$ & $361(78.1)$ & $228(85.0)$ & & \\
\hline Black or African-American & $77(10.5)$ & $57(12.3)$ & $20(7.5)$ & & \\
\hline Asian or Pacific Islander & $19(2.6)$ & $15(3.3)$ & $4(1.5)$ & & \\
\hline Other & $45(6.2)$ & $30(6.4)$ & $16(6.0)$ & & \\
\hline Ethnicity & & & & $3.2(1)$ & .076 \\
\hline Hispanic & $61(8.4)$ & $45(9.7)$ & $16(6.0)$ & & \\
\hline Not Hispanic (other) & $669(91.6)$ & $417(90.3)$ & $252(94.0)$ & & \\
\hline Education & & & & $1.0(1)$ & .307 \\
\hline$\leq$ High school & $223(30.5)$ & $135(29.2)$ & $88(32.8)$ & & \\
\hline$\geq$ College & $507(69.5)$ & $327(70.8)$ & $180(67.2)$ & & \\
\hline
\end{tabular}


Table 3. Bivariate statistics by time spent on Facebook $(n=461)$.

\begin{tabular}{|c|c|c|c|c|c|}
\hline Variable & $\begin{array}{l}\text { Stayed about the same } \\
(\mathrm{n}=241), \mathrm{n}(\%)\end{array}$ & $\begin{array}{l}\text { Increased } \\
(\mathrm{n}=61), \mathrm{n}(\%)\end{array}$ & $\begin{array}{l}\text { Decreased } \\
(\mathrm{n}=159), \mathrm{n}(\%)\end{array}$ & Chi-square (df) & $P$ value \\
\hline Age group (years) & & & & $31.8(6)$ & $<.001^{\mathrm{a}}$ \\
\hline $18-29$ & $55(22.8)$ & $12(19.7)$ & $61(38.4)$ & & \\
\hline $30-49$ & $75(31.1)$ & $29(47.5)$ & $59(37.1)$ & & \\
\hline $50-64$ & $65(27.0)$ & $17(27.9)$ & $27(17.0)$ & & \\
\hline $65+$ & $46(19.1)$ & $3(4.9)$ & $12(7.5)$ & & \\
\hline Sex & & & & $1.5(2)$ & .466 \\
\hline Male & $112(46.5)$ & $23(37.8)$ & $72(45.3)$ & & \\
\hline Female & $129(53.5)$ & $38(62.3)$ & $87(54.7)$ & & \\
\hline Income & & & & $7.4(4)$ & .118 \\
\hline$<\$ 30,000$ & $67(27.8)$ & $16(26.2)$ & $56(35.2)$ & & \\
\hline$\$ 30,000-\$ 100,000$ & $134(55.6)$ & $28(45.9)$ & $74(46.5)$ & & \\
\hline$>\$ 100,000$ & $40(16.7)$ & $17(27.9)$ & $29(18.3)$ & & \\
\hline Employment & & & & $5.3(4)$ & .255 \\
\hline Full-time & $123(51.0)$ & $26(42.6)$ & $88(55.4)$ & & \\
\hline Part-time & $32(13.3)$ & $13(21.3)$ & $26(16.4)$ & & \\
\hline Not employed & $86(35.8)$ & $22(36.1)$ & $45(28.3)$ & & \\
\hline Race & & & & $6.4(6)$ & $.363^{\mathrm{a}}$ \\
\hline White & $196(81.3)$ & $46(75.4)$ & $118(74.2)$ & & \\
\hline Black or African-American & $24(10.0)$ & $7(11.4)$ & $26(16.4)$ & & \\
\hline Asian or Pacific Islander & $6(2.5)$ & $4(6.7)$ & $5(3.1)$ & & \\
\hline Other & $15(6.2)$ & $4(6.7)$ & $10(6.4)$ & & \\
\hline Ethnicity & & & & $5.3(2)$ & $.045^{\mathrm{a}}$ \\
\hline Hispanic & 27 (11.2) & $1(1.6)$ & $17(10.7)$ & & \\
\hline Not Hispanic (Other) & $214(88.9)$ & $60(98.4)$ & $142(89.3)$ & & \\
\hline Education & & & & $3.2(2)$ & .204 \\
\hline$\leq$ High school & $75(31.1)$ & $12(19.7)$ & $48(30.2)$ & & \\
\hline$\geq$ College & $166(68.9)$ & $49(80.3)$ & $111(69.8)$ & & \\
\hline
\end{tabular}

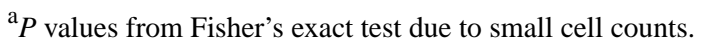


Table 4. Marginal effects of age group and sex on the probability of using Facebook.

\begin{tabular}{|c|c|c|}
\hline Variable & 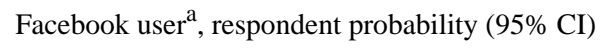 & $P$ value \\
\hline \multicolumn{3}{|c|}{ Age group (years) } \\
\hline $18-29$ & $0.87(0.82-0.92)$ & $<.001$ \\
\hline $30-49$ & $0.71(0.65-0.77)$ & $<.001$ \\
\hline $50-64$ & $0.58(0.51-0.65)$ & $<.001$ \\
\hline $65+$ & $0.36(0.27-0.44)$ & $<.001$ \\
\hline \multicolumn{3}{|l|}{ Sex } \\
\hline Male & $0.56(0.51-0.62)$ & $<.001$ \\
\hline Female & $0.73(0.69-0.78)$ & $<.001$ \\
\hline \multicolumn{3}{|c|}{ Age group by sex (years) } \\
\hline \multicolumn{3}{|l|}{ Male } \\
\hline $18-29$ & $0.83(0.76-0.89)$ & $<.001$ \\
\hline $30-49$ & $0.62(0.54-0.70)$ & $<.001$ \\
\hline $50-64$ & $0.48(0.40-0.57)$ & $<.001$ \\
\hline $65+$ & $0.27(0.19-0.36)$ & $<.001$ \\
\hline \multicolumn{3}{|l|}{ Female } \\
\hline $18-29$ & $0.91(0.87-0.95)$ & $<.001$ \\
\hline $30-49$ & $0.78(0.72-0.84)$ & $<.001$ \\
\hline $50-64$ & $0.67(0.59-0.74)$ & $<.001$ \\
\hline $65+$ & $0.45(0.35-0.54)$ & $<.001$ \\
\hline
\end{tabular}

${ }^{\mathrm{a}}$ Marginal effects from binary logistic regression, adjusted for income, employment status, ethnicity, race, and education.

Figure 1. Marginal effects of age group and sex on Facebook use.

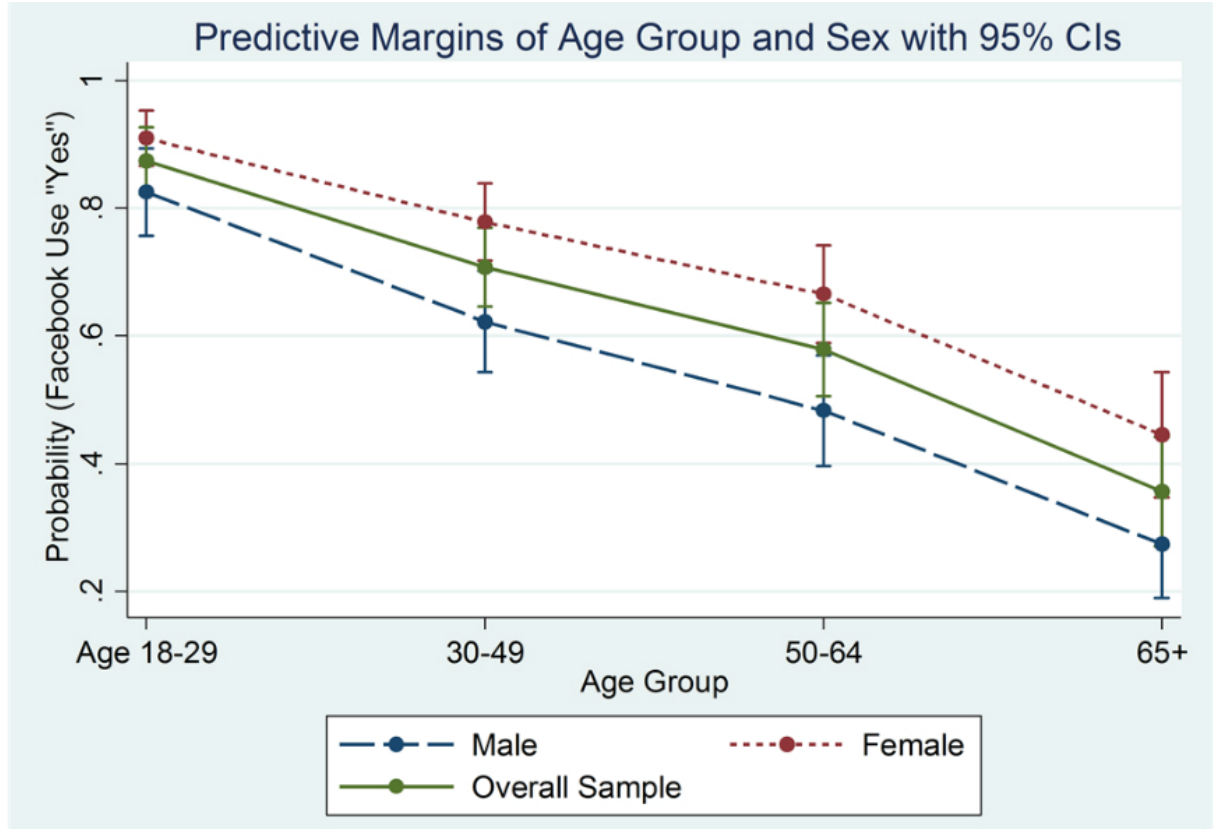


Table 5. Marginal effects of age group and sex on the probability of time on Facebook.

\begin{tabular}{|c|c|c|c|c|c|c|}
\hline Variable & $\begin{array}{l}\text { Stayed about the same }{ }^{a} \text {, } \\
\text { respondent probability } \\
(95 \% \mathrm{CI})\end{array}$ & $P$ value & $\begin{array}{l}\text { Increased }^{\mathrm{a}} \text {, respondent } \\
\text { probability }(95 \% \mathrm{CI})\end{array}$ & $P$ value & $\begin{array}{l}\text { Decreased }^{\mathrm{a}} \text {, respondent } \\
\text { probability }(95 \% \mathrm{CI})\end{array}$ & $P$ value \\
\hline \multicolumn{7}{|l|}{ Age group (years) } \\
\hline $18-29$ & $0.43(0.33-0.52)$ & $<.001$ & $0.08(0.03-0.14)$ & .001 & $0.49(0.40-0.58)$ & $<.001$ \\
\hline $30-49$ & $0.49(0.41-0.57)$ & $<.001$ & $0.15(0.09-0.21)$ & $<.001$ & $0.36(0.28-0.44)$ & $<.001$ \\
\hline $50+$ & $0.66(0.59-0.74)$ & $<.001$ & $0.10(0.05-0.14)$ & $<.001$ & $0.24(0.17-0.31)$ & $<.001$ \\
\hline \multicolumn{7}{|l|}{ Sex } \\
\hline Male & $0.58(0.50-0.65)$ & $<.001$ & $0.10(0.05-0.14)$ & $<.001$ & $0.32(0.26-0.39)$ & $<.001$ \\
\hline Female & $0.51(0.44-0.58)$ & $<.001$ & $0.12(0.08-0.17)$ & $<.001$ & $0.37(0.30-0.43)$ & $<.001$ \\
\hline \multicolumn{7}{|c|}{ Age group by sex (years) } \\
\hline \multicolumn{7}{|l|}{ Male } \\
\hline $18-29$ & $0.46(0.36-0.56)$ & $<.001$ & $0.08(0.03-0.13)$ & .003 & $0.46(0.36-0.56)$ & $<.001$ \\
\hline $30-49$ & $0.53(0.43-0.63)$ & $<.001$ & $0.13(0.06-0.20)$ & $<.001$ & $0.34(0.25-0.43)$ & $<.001$ \\
\hline Age $50+$ & $0.70(0.61-0.79)$ & $<.001$ & $0.08(0.03-0.13)$ & .001 & $0.22(0.14-0.30)$ & $<.001$ \\
\hline \multicolumn{7}{|l|}{ Female } \\
\hline $18-29$ & $0.40(0.29-0.51)$ & $<.001$ & $0.09(0.03-0.15)$ & .003 & $0.51(0.40-0.62)$ & $<.001$ \\
\hline $30-49$ & $0.46(0.37-0.55)$ & $<.001$ & $0.16(0.09-0.24)$ & $<.001$ & $0.38(0.29-0.47)$ & $<.001$ \\
\hline $50+$ & $0.64(0.55-0.72)$ & $<.001$ & $0.11(0.05-0.16)$ & .001 & $0.26(0.18-0.33)$ & $<.001$ \\
\hline
\end{tabular}

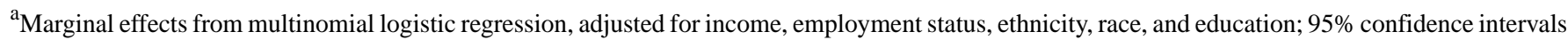
in parentheses.

Figure 2. Marginal effects of age group and sex by Facebook time "Stayed the Same".

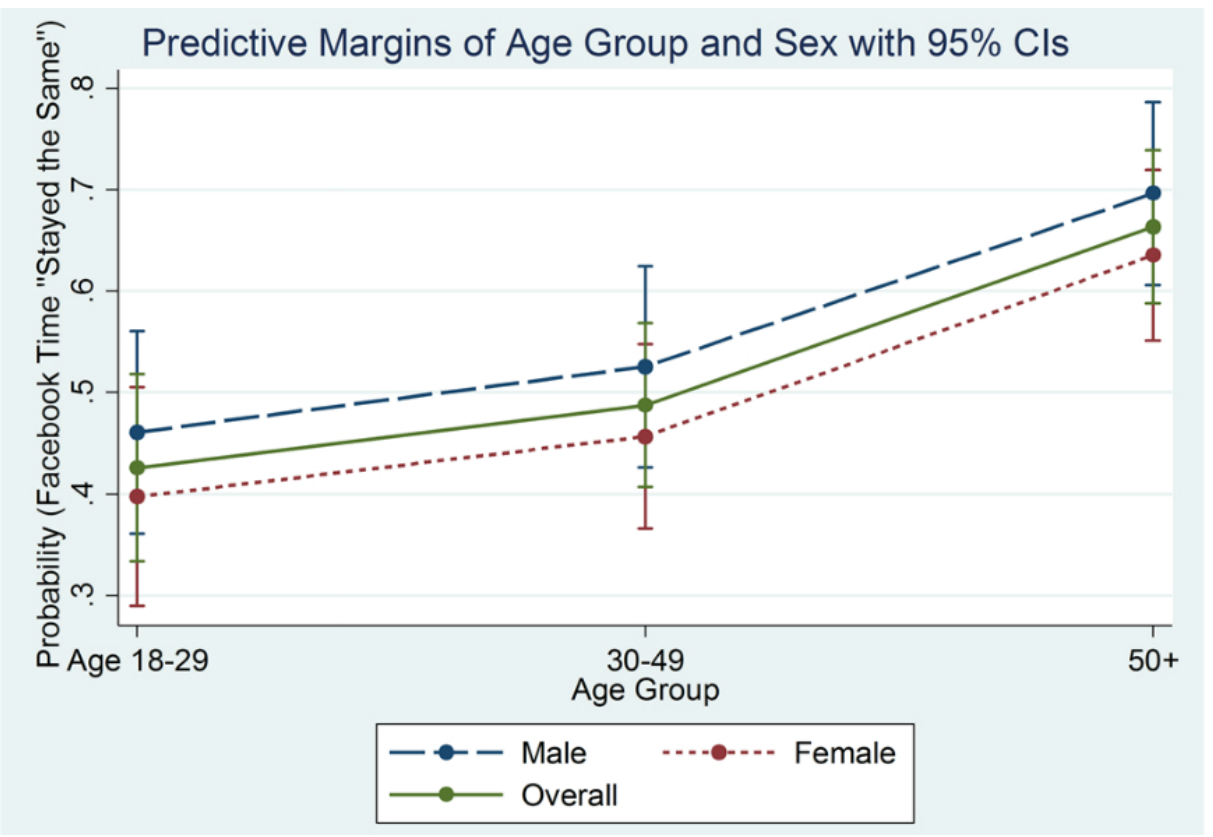


Figure 3. Marginal effects of age group and sex by Facebook time "Increased".

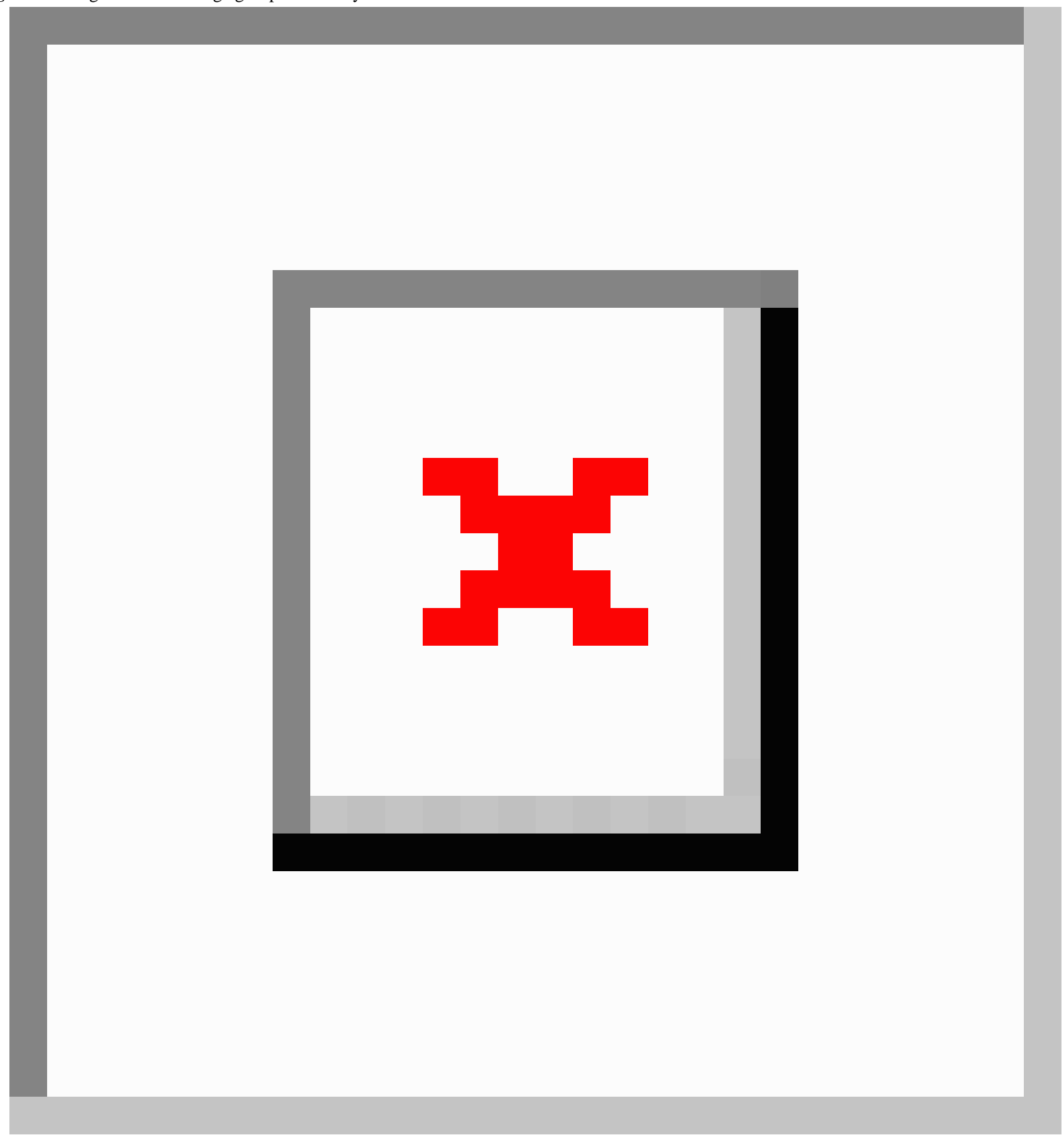


Figure 4. Marginal effects of age group and sex by Facebook time "Decreased".

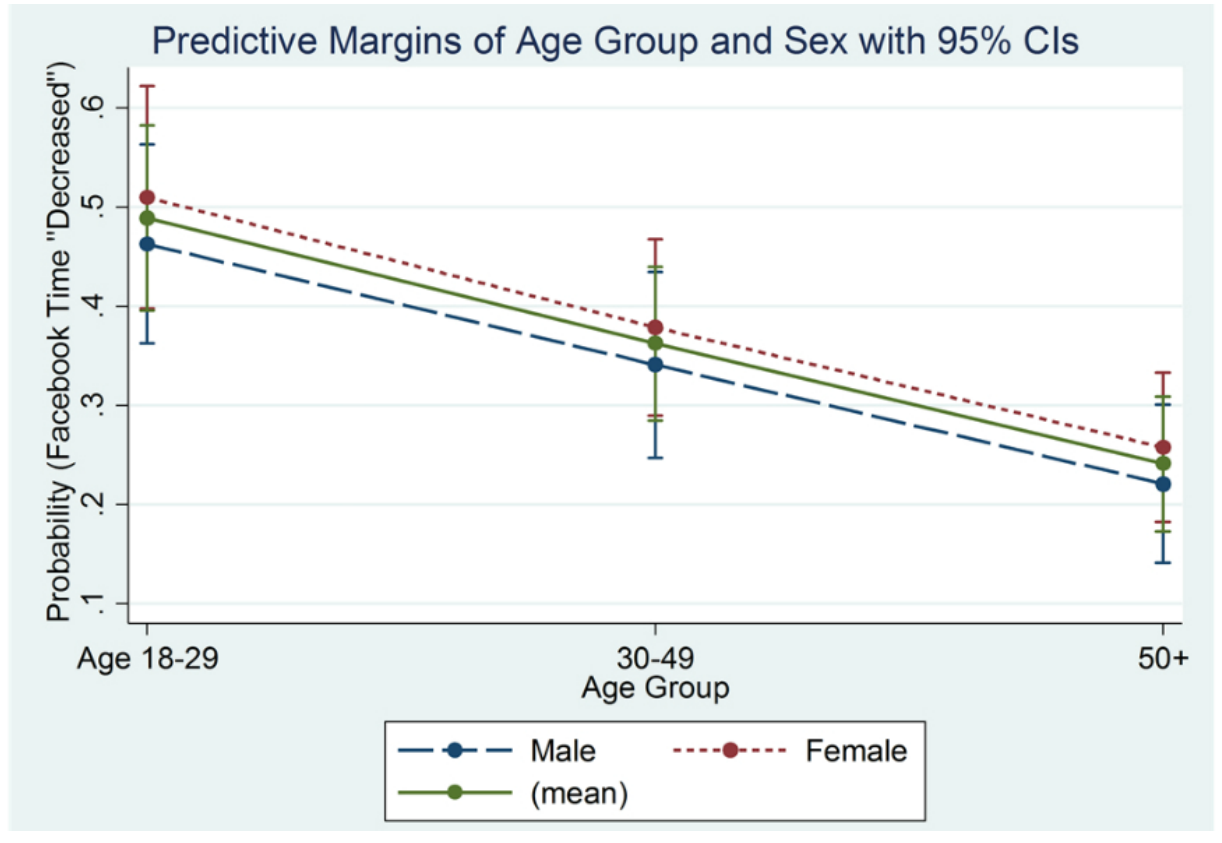

\section{Discussion}

\section{Principal Findings}

The key findings of this study were Facebook use among midlife adults was more likely to stay the same over time, compared to the other age groups. Interestingly, in the young adult age group, 18-29 years was more likely to decrease their time on Facebook over time. Based on the available data, we are not able to explain this finding but it may be due to the use of other competing social media platforms (eg, Twitter, Instagram, Snapchat, etc) and lifestyle factors unique to younger adults. Younger females were most likely to decrease time spent on Facebook. In general, male participants were most likely to spend the same amount of time on Facebook. The probability of increasing time on Facebook was low for both males and females.

Earlier reports indicated that midlife and older adults were unlikely to use social media to seek or discuss health information as it was perceived as an intrusion of privacy [21]. This age group was reportedly reluctant to learn about using the latest technology [3]. Our study findings contradict these perceptions and show that older adults had the highest probability of maintaining Facebook use over time. Our results demonstrated that older adults' use of Facebook stayed about the same over time, compared to decreased time in the younger age adult groups.

The reluctance of adults of any age to participate in social media may be related to a lack of awareness or familiarity with the technology. Facebook is the most widely used social media platform, and the user base has grown more representative of the broader population [18]. While young adults were among the earliest social media adopters and had high rates of social media use, use among midlife and older adults has increased considerably in recent years [18]. An update of the Pew Research Center survey data reported in early 2018 indicated that ownership of mobile phones used to access social media platforms has continued to grow to nearly three-quarters of adults in the United States [22]. In this update, adults age 18 to 49 years were found to be close to saturation adoption. This is nearly double the percentage measured in the Pew survey in 2012. Notably, the fastest growing demographic regarding Facebook use was with the midlife and older adult population.

The Facebook Groups platform with high levels of engagement, low levels of attrition over time, and wide reach holds promise to motivate and support health behavior change for the growing population of midlife adults. Providing technical assistance for midlife and older adults with mobile device use and navigating the Facebook Groups platform must be considered to improve use for this age group when developing health behavior interventions.

Considerations for generalizing these findings to other populations include the representative sample of adults within the continental United States and the global reach of the Facebook platform. The wide geographical sampling distribution strengthens the Pew Research Center data for generalization to US adults, but may not be representative of the global population. We also acknowledge that secondary analyses of existing data are limited to the variables in the dataset, and this can be considered a limitation. We acknowledge that the variables used in this analysis may not be sufficient to account for other unmeasured factors related to our outcome variables. However, the sociodemographic variables examined, Facebook use and nonuse variables, and Facebook use over time support our study objective.

\section{Conclusion}

Overall, the findings of this study point to considerations for researchers to use the Facebook Groups platform to facilitate health behavior interventions. In addition to social communication and interaction, this platform is capable of providing health information, motivation and support for positive health behavior change. This platform can be integrated with clinic processes, involving health care professionals as moderators and contributors to ensure the veracity of the content. 
Providing a health behavior intervention on a social media platform is a unique approach to improve health outcomes, specifically, with the large and growing midlife adult population with escalating risk for chronic conditions. Our data indicate more consistent Facebook use among midlife adults than younger adults. Prospective research is needed to determine if the levels of engagement and retention of Facebook use for general social networking purposes translates to health behavior interventions facilitated by the Facebook Groups platform.

\section{Conflicts of Interest}

None declared.

\section{References}

1. Pampel FC, Krueger PM, Denney JT. Socioeconomic Disparities in Health Behaviors. Annu Rev Sociol 2010 Aug;36:349-370 [FREE Full text] [doi: 10.1146/annurev.soc.012809.102529] [Medline: 21909182]

2. Smith KP, Christakis NA. Annual Review of Sociology. Palo Alto, CA 94306 USA: Annual Reviews; 2008 Mar 24. Social Networks and Health URL: https://www.annualreviews.org/doi/10.1146/annurev.soc.34.040507.134601 [accessed 2018-05-09] [WebCite Cache ID 6zI8sBqD9]

3. Aaron S. Pew Research Center Internet \& Technology. Washington, DC 20036 USA: Pew Research Center; 2014 Apr 03. Older adults and technology use URL: http://www.pewinternet.org/2014/04/03/older-adults-and-technology-use/ [accessed 2018-05-09] [WebCite Cache ID 6zI4nec2f]

4. Facebook. Facebook Newsroom. Menlo Park, California 94025 USA: Facebook; 2017. Company Info URL: https://newsroom. fb.com/company-info/ [accessed 2018-05-09] [WebCite Cache ID 6zI5xpi2e]

5. Whitaker C, Stevelink S, Fear N. The Use of Facebook in Recruiting Participants for Health Research Purposes: A Systematic Review. J Med Internet Res 2017 Aug 28;19(8):e290 [FREE Full text] [doi: 10.2196/jmir.7071] [Medline: 28851679]

6. Dagan N, Beskin D, Brezis M, Reis BY. Effects of Social Network Exposure on Nutritional Learning: Development of an Online Educational Platform. JMIR Serious Games 2015;3(2):e7 [FREE Full text] [doi: 10.2196/games.4002] [Medline: $\underline{26441466]}$

7. Nicolai L, Schmidbauer M, Gradel M, Ferch S, Antón S, Hoppe B, et al. Facebook Groups as a Powerful and Dynamic Tool in Medical Education: Mixed-Method Study. J Med Internet Res 2017 Dec 22;19(12):e408 [FREE Full text] [doi: 10.2196/jmir.7990] [Medline: 29273572]

8. Cavallo DN, Tate DF, Ries AV, Brown JD, DeVellis RF, Ammerman AS. A social media-based physical activity intervention: a randomized controlled trial. Am J Prev Med 2012 Nov;43(5):527-532 [FREE Full text] [doi: 10.1016/j.amepre.2012.07.019] [Medline: 23079176]

9. Cavallo DN, Tate DF, Ward DS, DeVellis RF, Thayer LM, Ammerman AS. Social support for physical activity-role of Facebook with and without structured intervention. Transl Behav Med 2014 Dec;4(4):346-354 [FREE Full text] [doi: 10.1007/s13142-014-0269-9] [Medline: 25584083]

10. Napolitano MA, Hayes S, Bennett GG, Ives AK, Foster GD. Using Facebook and text messaging to deliver a weight loss program to college students. Obesity (Silver Spring) 2013 Jan;21(1):25-31. [doi: 10.1002/oby.20232] [Medline: 23505165]

11. Valle CG, Tate DF, Mayer DK, Allicock M, Cai J. A randomized trial of a Facebook-based physical activity intervention for young adult cancer survivors. J Cancer Surviv 2013 Sep;7(3):355-368 [FREE Full text] [doi: 10.1007/s11764-013-0279-5] [Medline: 23532799]

12. Pagoto S, Waring ME, May CN, Ding EY, Kunz WH, Hayes R, et al. Adapting Behavioral Interventions for Social Media Delivery. J Med Internet Res 2016;18(1):e24 [FREE Full text] [doi: 10.2196/jmir.5086] [Medline: 26825969]

13. Barello S, Triberti S, Graffigna G, Libreri C, Serino S, Hibbard J, et al. eHealth for Patient Engagement: A Systematic Review. Front Psychol 2015;6:2013 [FREE Full text] [doi: 10.3389/fpsyg.2015.02013] [Medline: 26779108]

14. Wang J, Wang Y, Wei C, Yao NA, Yuan A, Shan Y, et al. Smartphone interventions for long-term health management of chronic diseases: an integrative review. Telemed J E Health 2014 Jun;20(6):570-583. [doi: 10.1089/tmj.2013.0243] [Medline: 24787747]

15. Maher CA, Lewis LK, Ferrar K, Marshall S, De BI, Vandelanotte C. Are health behavior change interventions that use online social networks effective? A systematic review. J Med Internet Res 2014;16(2):e40 [FREE Full text] [doi: 10.2196/jmir.2952] [Medline: 24550083]

16. Kim SJ, Marsch LA, Brunette MF, Dallery J. Harnessing Facebook for Smoking Reduction and Cessation Interventions: Facebook User Engagement and Social Support Predict Smoking Reduction. J Med Internet Res 2017 May 23;19(5):e168 [FREE Full text] [doi: 10.2196/jmir.6681] [Medline: 28536096]

17. Siegmund LA, Ahmed HM, Crawford MT, Bena JF. Feasibility of a Facebook Intervention for Exercise Motivation and Cardiac Rehabilitation Adherence: Study Protocol. JMIR Res Protoc 2017 Aug 18;6(8):e162 [FREE Full text] [doi: 10.2196/resprot.7554] [Medline: 28821473]

18. Pew Research Center. Pew Research Center Internet \& Technology. Washington, DC 20036 USA: Pew Research Center; 2018 Feb 05. Social Media Fact Sheet URL: http://www.pewinternet.org/ [accessed 2018-05-09] [WebCite Cache ID 6zI6NMs1C] 
19. Fox S, Duggan M. Pew Research Center Internet \& Technology. Washington, DC 20036 USA: Pew Research Center; 2012 Nov 08. Mobile Health 2012 URL: http://www.pewinternet.org/2012/11/08/mobile-health-2012/ [accessed 2018-05-09] [WebCite Cache ID 6zI6cw96f]

20. Pew Research Center. Pew Research Center Internet \& Technology Datasets 2012. Washington, DC 20036 USA: Pew Research Center; 2012 Dec 13. Facebook URL: http://www.pewinternet.org/datasets/2012/ [accessed 2018-05-09] [WebCite Cache ID 6zI7COM8v]

21. Fox S, Duggan M. Pew Research Center Internet \& Technology. Washington, DC 20036 USA: Pew Research Center; 2013 Jan 15. Health Online 2013 URL: http://www.pewinternet.org/2013/01/15/health-online-2013/ [accessed 2018-05-09] [WebCite Cache ID 6zI9g5rSE]

22. Anderson M. Pew Research Center Internet \& Technology. Washington, DC 20036 USA: Pew Research Center; 2015 Oct 29. Technology Device Ownership: 2015 URL: http://www.pewinternet.org/2015/10/29/technology-device-ownership-2015/ [accessed 2018-05-09] [WebCite Cache ID 6zIA7BSXW]

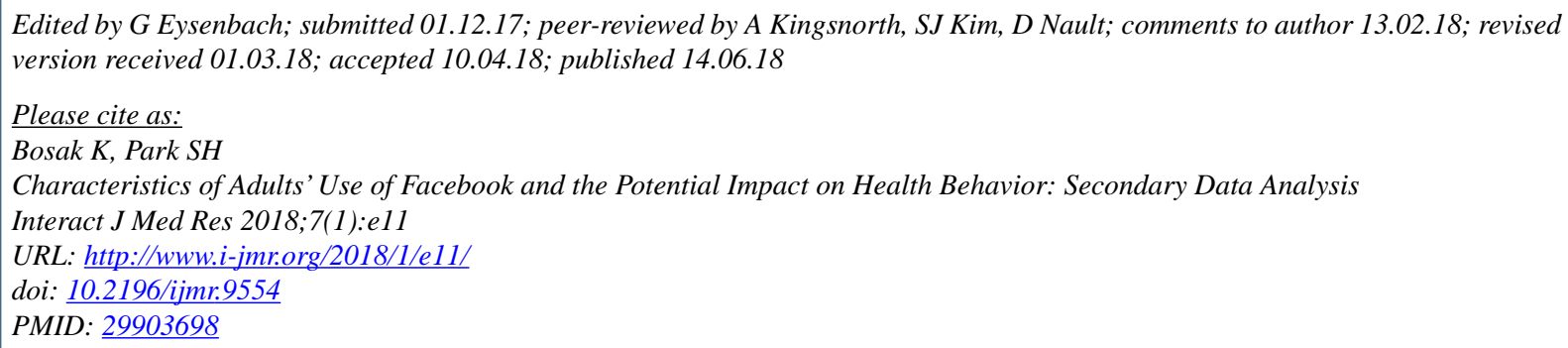

CKelly Bosak, Shin Hye Park. Originally published in the Interactive Journal of Medical Research (http://www.i-jmr.org/), 14.06.2018. This is an open-access article distributed under the terms of the Creative Commons Attribution License (https://creativecommons.org/licenses/by/4.0/), which permits unrestricted use, distribution, and reproduction in any medium, provided the original work, first published in the Interactive Journal of Medical Research, is properly cited. The complete bibliographic information, a link to the original publication on http://www.i-jmr.org/, as well as this copyright and license information must be included. 